pole-vault - an event that requires both sprinting and jumping ability - is almost entirely white, as are field events such as discus, javelin and shot-put.

Entine points out that a cluster of South Pacific islands, such as Samoa and Fiji, have in recent years produced an extraordinary number of American football and Australian rugby players. Such islanders, Entine argues, "tend to be large and explosively fast", implying that their success somehow gives credence to his 'blacks are bred to run' thesis. In fact it does the opposite: genetically, there are few populations in the world more different from sub-Saharan Africans than Pacific islanders. For whatever reason Fijians and Samoans excel at sport, it is not because they genetically resemble Nigerians or Kenyans.

The most irritating aspect of Taboo is Entine's constant dismissal of critics - who include the eminent scientists Richard Lewontin and Luigi Luca Cavalli-Sforza as "postmodernists", or simply motivated by ideology. Such bluster cannot hide the gaping holes in his argument. Is athletic talent at least in part inherited? Undoubtedly. Are there genetic differences between populations? Clearly. Are West Africans and Kenyans genetically built for running? Possibly. Are blacks naturally better athletes than whites? Not necessarily. After all, how many African pygmies have you seen garlanded with Olympic medals?

Kenan Malik is a freelance writer living in London, UK (e-mail:kenanmalik@msn.com).

\section{At the edges of life}

\section{Life at the Extremes: The Science of Survival \\ by Frances Ashcroft \\ HarperCollins: 2000. 326 pp. £17.99, \$24.95}

\section{Knut Schmidt-Nielsen}

When we venture to the edge of livable conditions, or even beyond, the results are not always pretty: altitude sickness, diver's disease, frostbite, heat stroke and so on. Frances Ashcroft, who describes such nasty events in this book, is a venturesome woman. Preceding each of her first four chapters is a tale of her own encounters with the effects of altitude, diving, heat and cold. Further chapters discuss the ultimate physical performance needed in competitive sports, and the physiological and technical problems of space travel. There is also a look at the extraordinary organisms that thrive in conditions beyond what any human would dream of tolerating.

Ashcroft gives much interesting historical information which helps us understand the dangers faced by mountain climbers, early balloonists and divers, many of whom paid for their experiences with their lives. She also gives fascinating accounts of how our knowl-

\title{
From one extreme to another
}

Two years after having brain surgery and chemotherapy for stage-four testicular cancer, US cyclist Lance Armstrong won the 1999 Tour de France. His autobiography, It's Not About the Bike: My Journey Back to Life, written with Sally Jenkins (Yellow Jersey Press/Putnam; $\mathfrak{E 1 7 / \$ 2 4 . 9 5 ) , ~ r a c e s ~ t h r o u g h ~}$ his childhood in Texas, the chivalric code of the peloton, his existence during chemotherapy and his emergence as both a strategist and a sprinter fit to conquer time trials and mountain routes alike in the 1999 Tour. He was left for dead in a cancer ward by his then sponsors, Cofidis, only to be tipped by Miguel Indurain, winner of five consecutive Tours, to win the 1999 Tour. He met his wife while setting up the Lance Armstrong Foundation for cancer patients and survivors. The book is a raw and gripping read written in pure testoterone - quite an achievement for a woman ghost writer.

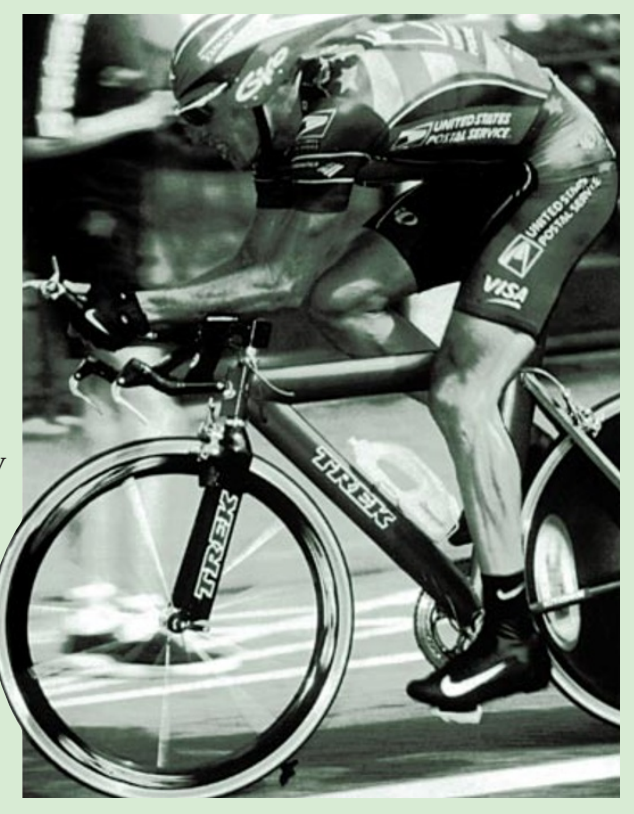

edge of human physiology has progressed and now forms the basis for our understanding of the limits to human accomplishment.

We can follow the superhuman efforts of the men who reached the 8,848-metre summit of Mount Everest. Many climbers died trying to conquer the world's highest peak, suffering from the lack of oxygen and freezing temperatures. The top was finally reached in 1953 with the aid of extra oxygen; amazingly, it has since been scaled without this.

The increased pressure encountered in diving has serious dangers. Whether we use scuba equipment or a diver's suit, the gases we breathe are at the same pressure as the surrounding water, and with increasing pressure as we dive deeper the gases we normally breathe, oxygen and nitrogen, become toxic and narcotic. Worse, they become dissolved in blood and body fluids, and when we return to the lower pressure at the surface, the dissolved nitrogen bubbles out of solution, causing the painful and often lethal condition known as diver's disease, or the bends.

If humans suffer from the bends after diving beyond some ten metres, how can whales and seals avoid them when diving to more than 1,000 metres? Simple. When they begin a dive, they exhale, so there is no gas in their lungs to enter the blood and cause trouble when they surface.

Our tolerance of heat is limited, and without enough drinking water, a single day in a hot desert is likely to end in a miserable death. But in 1775 the Secretary of the Royal Society, Mr Blagden, had a room heated to well above boiling point, and, together with a dog and a piece of raw meat, he entered the room at 105 ${ }^{\circ} \mathrm{C}$. When he left it 15 minutes later, he and the dog were fine, but the steak was well done.
Ashcroft describes well how humans cope with cold, and her accounts of polar expeditions give us an insight into the limits of human endurance. The conditions that some polar explorers have suffered are astounding. A few photographs show effects of frostbite so appalling that one almost wishes they were as poorly reproduced as some of the other photos, which are so dark as to be indecipherable.

In the chapter on space, I learned that a space suit weighs a formidable 113 kilograms, although in space, of course, it is weightless. We also learn that a sudden decompression in space would cause immediate death as all air rushes out of the lungs, gas in the intestine expands explosively, and blood and body fluids boil — a grim but swift end.

We learn in the last chapter about the peculiar organisms that live around the black smokers in the deep ocean, where superheated water laden with hydrogen sulphide emerges. Strange invertebrates, known nowhere else, depend on bacteria that gain energy from the oxidation of the otherwise toxic hydrogen sulphide. We also meet other creatures that endure, and even prefer, extreme conditions.

The book is generally well and clearly written at a level suitable for non-physiologists. Ashcroft is at her best when she explains what happens to humans under extreme conditions. These explanations are easy to grasp, and the author only occasionally falls into the trap of using scientific jargon. For example, in a book like this there is no need to show the complex chemical structure of adenosine triphosphate, or to explain that Heisenberg's uncertainty principle means that all molecular motion does not cease at absolute zero. The book is much too readable 
and interesting to load it with such minor excursions into scientific technicalities. Knut Schmidt-Nielsen is in the Department of Biology, Duke University, Durham, North Carolina 27708-0338, USA.

\section{Surfing the nebulae, churning the waters}

\author{
From Galaxies to Turbines: \\ Science, Technology and the \\ Parsons Family \\ by W. Garrett Scaife

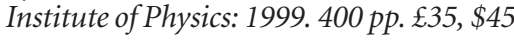

\section{J. L. Heilbron}

In 1845 Dean Peacock of the Church of Ireland strutted in top hat, with umbrella unfurled, through a wooden barrel 46 feet long. His parade was part of the inauguration of the Leviathan of Parsonstown, the six-foot mirror that, together with the barrel, made up the world's biggest telescope. Two masonry walls, each 50 feet high and 70 feet long, supported the instrument on the grounds of Birr Castle, the seat of the Earl of Rosse in County Offaly, central Ireland. The designer and builder of the telescope was the Earl's son and heir, William Parsons.

In 1897 the first turbine-driven ship, the Turbinia, demonstrated its unique speed and efficiency at the jubilee regatta held in honour of England's Queen Victoria. The Turbinia had not been invited. She brazenly sailed in and out among the great ships, easily eluding the torpedo boats assigned to intercept interlopers. The bold sailor and self-promoter, the inventor of the marine turbine, was Charles A. Parsons, the tenth child and youngest son of the creator of the outsized telescope.

William built as much of his telescope as he could in workshops around Birr Castle staffed by local men he had trained as mechanics and opticians. He encouraged all his children, the girls as well as the boys, to experiment in the workshops. His wife Mary, whose fortune helped to defray the astronomical cost of the Leviathan, also spent time there and became an adept photographer. Charles's eldest brother Laurence, who inherited the estate, continued the work on the telescope; but whereas William had built the instrument to study the structure of the most distant objects then known, the nebulae, which he did to general approval, Laurence used it to take the temperature of the nearest, the Moon, which met with undeserved coldness in the academic establishment. Nonetheless Laurence followed his father into the Royal Society; Charles also became a fellow. One of their brothers had a successful career as an engineer. Various Parsons nephews and relatives of William's workmen also had talents for technology and found places in Charles's enterprises.
Although Charles attended Cambridge, from which he emerged eleventh wrangler in 1877, he followed his father's style of invention: by inspired cut-and-try. Just as William had experimented tirelessly with the make-up of speculum metals and the techniques of pouring, cooling, annealing, grinding and polishing them, Charles varied the number, orientation and shape of the turbine blades, the velocity of the steam through the turbine, the lubrication and placing of the bearings, and so on, until he had maximized performance. Modern modelling confirms that the propulsion package of the Turbinia was near optimal for the ungeared drive system Parsons invented.

Few nineteenth-century Oxbridge men and still fewer members of the landed aristocracy were willing to labour for days with workmen, to endure physical hardship or to neglect personal comfort in order to make mirrors smoother or rotors better. Garrett Scaife credits the Parsons' obsession, or anyway its indulgence, to their avoidance of English public schools. In Ireland one could be a lord and a gentleman while also devoting one's time to manual work.

The family obsession and creativity appeared most obviously in Charles, to whom Scaife devotes most of his book. As the youngest son, Charles felt he had to work for a living. A measure of his mettle is that, after losing his first patents on the turbine to partners from whom he had parted, he did not think to quit or to compromise. He invented another type of steam turbine, and no doubt would have persisted with it had his former partners not changed their minds and sold him the original patents at less than $2 \%$ of what they had originally demanded. With this sort of grit came irascibility and even irrationality. But Parsons could also be gentle and generous when alerted to the troubles of people around him. Although often in the company of distinguished men, he was not at ease in society. His wife Katherine, the tenth child and youngest daughter of landed gentry in Yorkshire, recalled that when they met "he had the character of being an extraordinary and weird young man socially but it was understood that he was a genius".

The "genius" invented or improved many things besides steam turbines. He began with an unsuccessful rotary engine, went on to torpedoes, designed electrical apparatus, found a way to mould parabolic mirrors, failed to make diamonds, and did much else. But propulsion was his compulsion. He devoted himself with such energy to perfecting the marine steam turbine that only a decade after Turbinia had demonstrated its feasibility he began to build a propulsive plant with 16 times its power. The result of this scale-up was designed to drive the Mauretania, which would be the largest ship in the world.

Parsons did not care to monopolize his businesses or drive hard bargains. He paid himself no salary, obtaining from the works enough to maintain his development programmes and satisfy his shareholders. His main backers, aristocrats enlisted by Laurence and wealthy men interested in the technical progress of the turbine, gave him a free hand in choosing his projects, staff and business.

He was not a good manager, but was astute enough to act on suggestions from people who were. He gave one of his nephews, who had learned industrial management at Westinghouse, responsibility for introducing USstyle efficiency. The nephew's brief did not extend to machinery. In the 1920s engineers from a big shipbuilder in Hamburg came to see Parsons' shops. They were impressed: "It is wonderful how you achieve such accuracy with such old-fashioned machinery." A programme of retooling followed.

Constant work and an irascible temper did not make Charles a good family man. His wife spent her time improving the huge estate Charles bought to indulge his passion for hunting. The First World War made her a champion of women's rights in the workplace. Many women learned to be excellent mechanics when their men went off to fight, but at the war's end most were let go. Parsons' works participated in this general pattern, with the notable complication that one of the women engaged in a senior position was his daughter Rachel, who had studied engineering at Cambridge. She soon left for a government job and later had a position in a factory set up by her mother and run by women. The only son of the family was killed at the front.

Parsons' engineering works barely survived the war. But with the help of friends and the Second World War it came to prosper again. In 1953 it received a contract for the generators of the world's first nuclear power plant. For a few decades more it carried on as the only large manufacturer in its field not owned by a foreign firm. This happy state ended in 1997, when Siemens acquired "C. A. Parsons Works". They have retained the name.

Parsons' business brought him into frequent contact with officers of the Royal Navy and with politicians and other administrators. Scaife supplies anecdotes about their ignorance of technical matters. Parsons often

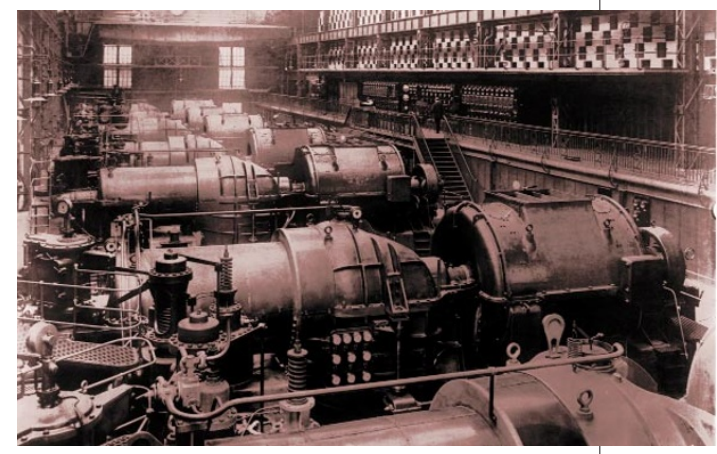

Energetic applications: Charles Parsons' steam turbines were used in the Carville power station. 